\title{
The interplay between cationic polyethyleneimine and anionic polyelectrolytes for the control of silica scale formation in process waters
}

\author{
A. Spinthaki, A. Stathoulopoulou and K. D. Demadis* \\ Crystal Engineering, Growth and Design Laboratory, Department of Chemistry, \\ University of Crete, Voutes Campus, Crete, GR-71003, Greece \\ E-mail:demadis@,chemistry.uoc.gr
}

\begin{abstract}
Stabilization of mono- and disilicic acids is accomplished by using a cationic polymeric chemical additive, polyethyleneimine (PEI), in supersaturated silica solutions (the starting solution contained $500 \mathrm{ppm} / 8.3 \mathrm{mM}$ sodium orthosilicate, $\mathrm{Na}_{2} \mathrm{SiO}_{3} \cdot 5 \mathrm{H}_{2} \mathrm{O}$, expressed as $\left.\mathrm{SiO}_{2}\right)$ at $\mathrm{pH}=7$. The PEI polymeric system contains an excess of amine groups $(\sim 25 \%$ primary amines, $\sim 50 \%$ secondary amines and $\sim 25 \%$ tertiary amines) that become protonated at circumneutral $\mathrm{pH}$, hence charging the molecules positively. PEI was found to be efficient as a silica scale inhibitor only at the low dosage of $10 \mathrm{ppm}$. Its inhibitory activity was found to drop as its concentration increased. It was hypothesized that PEI is entrapped into the colloidal silica matrix and deactivated. Thus, one way to maintain its activity was to create blends of PEI and anionic polymers. Anionic polyelectrolytes that were tested included polyacrylic acid (PAA), phosphonated polyacrylic acid (PAA $\left.\left(\mathrm{PO}_{3} \mathrm{H}_{2}\right)_{2}\right)$, carboxymethylinulin $(\mathrm{CMI})$, poly(acrylamide-co-acrylic acid) (PAM-co$\mathrm{AA})$, phosphonomethylated chitosan $(\mathrm{PCH})$ are also studied for their silica scale inhibition efficiency. It is observed that the silica inhibitory activity of PEI was improved upon its combination with anionic polyelectrolytes.
\end{abstract}

Key words: silicic acid stabilization, water systems, inhibitors, polyethyleneimine, PEI, scale, silica deposits, water treatment.

Received: January 7, 2015.

doi: $\underline{10.17675 / 2305-6894-2015-4-2-125-138}$

\section{Introduction}

Due to its notable heat capacity and cost-effectiveness, water is thought to be the most efficient cooling medium used in industry at a global scale [1]. However, its re-use is commonly obligatory, when operations are installed in arid areas, or substantial savings in water utilization are sought [2]. During its re-use, scaling and deposition can develop due to the high content of dissolved species [3]. The identity of the scale deposits depends on the particular water chemistry [4-8]. Among the water-formed deposits colloidal silica $\left(\mathrm{SiO}_{2} \cdot n \mathrm{H}_{2} \mathrm{O}, n\right.$ is variable and dependent on hydration), a very persistent precipitate, is 
especially troublesome, as it can cause serious materials failure and operational shutdowns, Figure 1 [9-13].

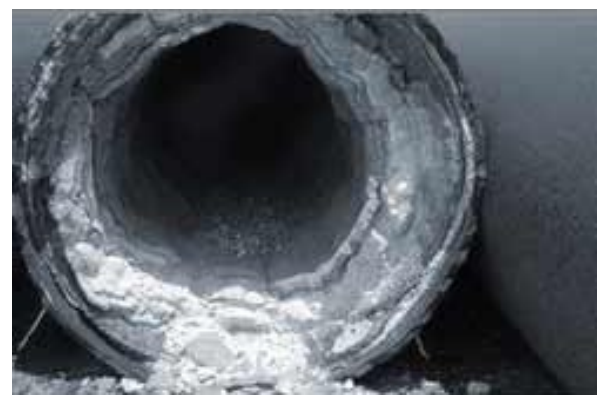

Figure 1. Amorphous silica deposits on industrial equipment. Reproduced from http://www.chemtexlimited.com.

Silica scale control can be achieved in two ways: $(a)$ by silica species removal before the silica-laden water enters the operation [14], and $(b)$ by use of chemical additives as silica scale inhibitors [15]. Although traditional scale control methods (inhibition and crystal modification) are amply available for crystalline mineral scale salts [16], analogous strategies do not apply to silica because of its amorphous state [17]. Therefore, much more well-designed inhibition approaches have to be applied for controlling silica formation and deposition.

In this paper we report on the inhibitory efficiency of polyethyleneimine (PEI, Figure 2) in preventing silica formation, by stabilizing silicic acid. The branched PEI that was used in our work contains $\sim 25 \%$ primary amines, $\sim 50 \%$ secondary amines and $\sim 25 \%$ tertiary amines. These moieties are protonated at $\mathrm{pH} \sim 7$. Furthermore, because PEI generates silica-PEI composite precipitates and, thus, becomes entrapped within the silica matrix, it was combined with a variety of anionic polyelectrolytes (Figure 3). It was found that its inhibitory efficiency increased as a result of these synergistic mixtures. This research is part of our on-going investigation on the discovery and application of scale inhibitors in industrial process waters [18-32]. 


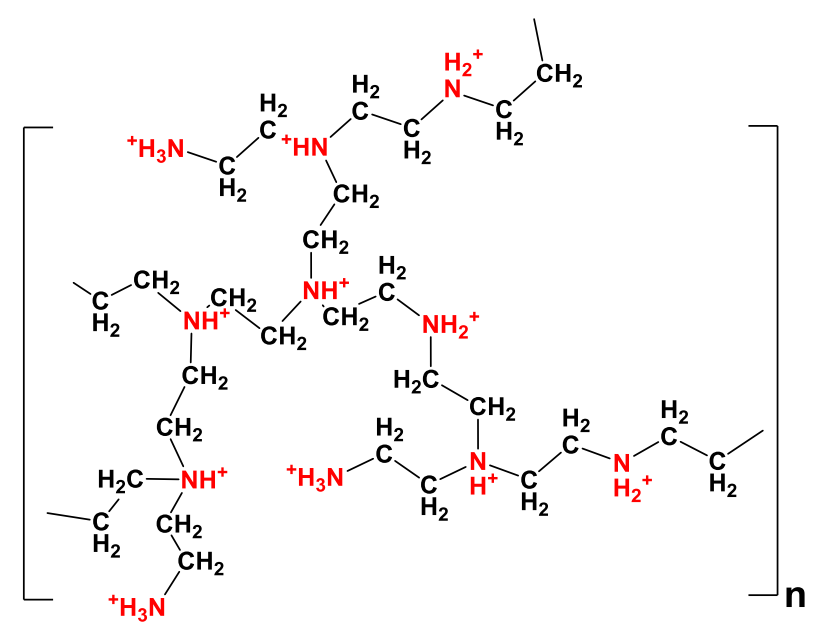

Figure 2. Structure of polyethyleneimine (PEI) in its cationic form, highlighted in red.

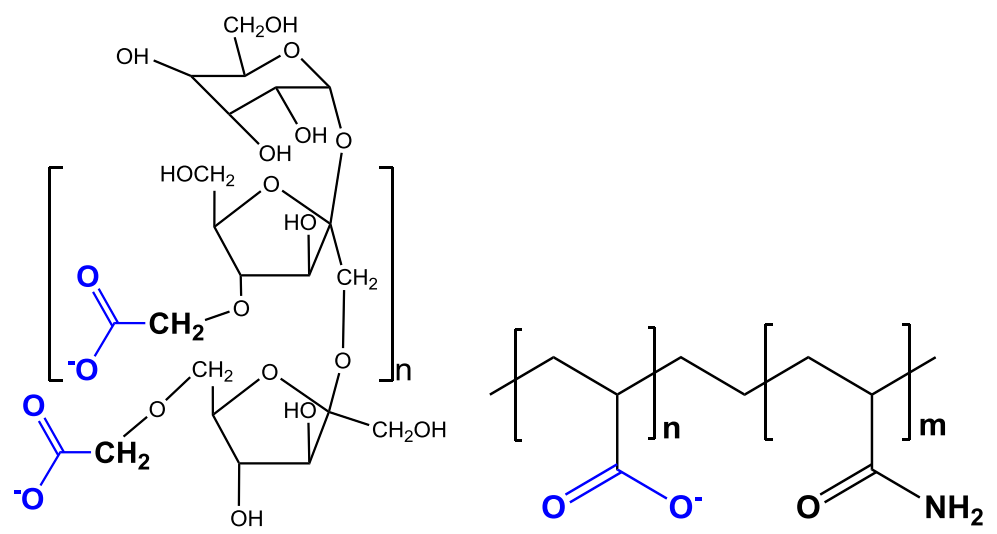

Carboxymethylinulin (CMI) Poly(acrylamide-co-acrylic acid) (PAM-co-AA)
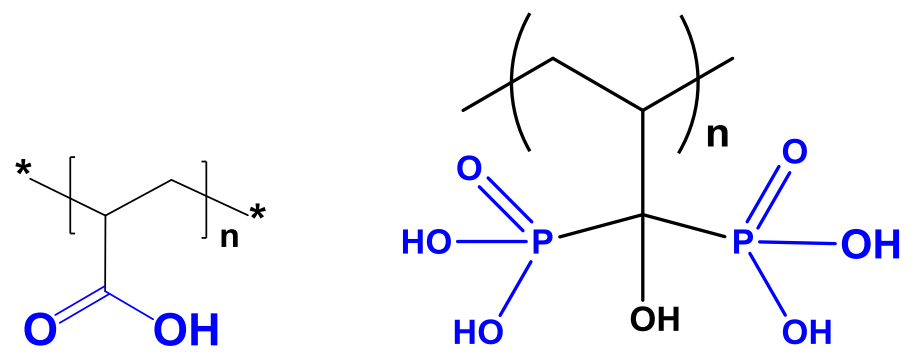

Polyacrylic acid (PAA) Phosphonated polyacrylic acid $\left(\mathrm{PAA}\left(\mathrm{PO}_{3} \mathrm{H}_{2}\right)_{2}\right)$

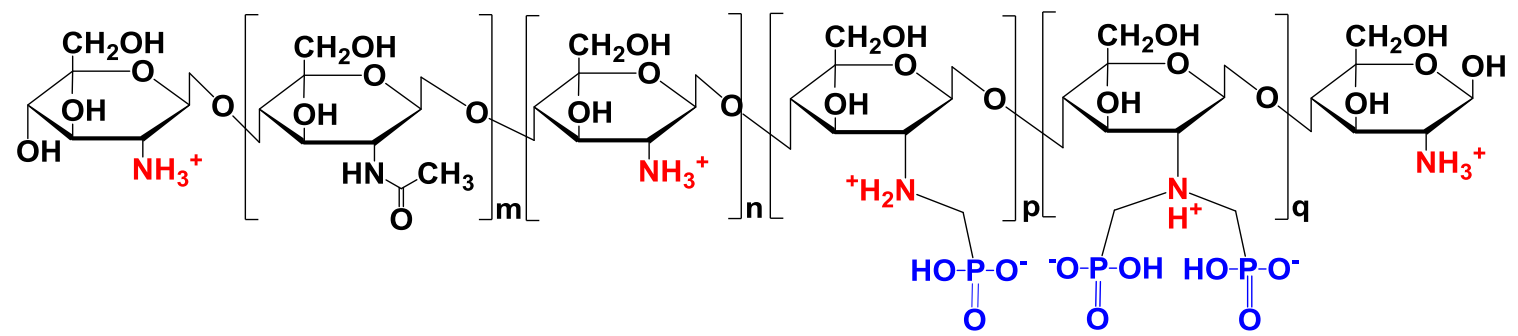

Phosphonomethylated chitosan $(\mathrm{PCH})$ 
Figure 3. Structures of the silica scale co-inhibitors used in this work. Cationic groups are highlighted in red, anionic ones in blue.

\section{Experimental section}

\section{Instruments}

The measurements of soluble silicic acid were carried out with a HACH 890 spectrophotometer from the Hach Co., Loveland, CO, U.S.A. IR spectra were recorded on a FT-IR Perkin - Elmer FT 1760.

\section{Reagents and chemicals}

Polyethyleneimine (PEI, branched, MW $70 \mathrm{kDa}, \sim 25 \%$ primary amines, $\sim 50 \%$ secondary amines and $\sim 25 \%$ amines) was from Polysciences, USA. PAA and PAM-co-AA was from Aldrich. CMI was a commercial product from ThermPhos, Switzerland. PAA $\left(\mathrm{PO}_{3} \mathrm{H}_{2}\right)_{2}$ was synthesized by a reaction of PAA with $\mathrm{PCl}_{3} / \mathrm{H}_{3} \mathrm{PO}_{3}$ in water, as published before [33]. $\mathrm{PCH}$ was synthesized according to literature procedures [34]. Sodium silicate pentahydrate, $\mathrm{Na}_{2} \mathrm{SiO}_{3} \cdot 5 \mathrm{H}_{2} \mathrm{O}$, was purchased from Sigma Aldrich. Ammonium molybdate $\left(\left(\mathrm{NH}_{4}\right)_{6} \mathrm{Mo}_{7} \mathrm{O}_{24} \cdot 4 \mathrm{H}_{2} \mathrm{O}\right)$ was obtained from Alfa Aesar and oxalic acid $\left(\mathrm{H}_{2} \mathrm{C}_{2} \mathrm{O}_{4} \cdot 2 \mathrm{H}_{2} \mathrm{O}\right)$ from EM Science (Merck). Sodium hydroxide $(\mathrm{NaOH})$ and hydrochloric acid $(\mathrm{HCl}) 37 \%$ were purchased from Sigma Aldrich. Deionized water from an ion-exchange resin was used for all experiments and stock preparations. This water was tested for molybdate-reactive silica and were found to contain negligible amounts.

\section{Preparation of sodium silicate solutions ("stock" solutions)}

A solution containing silicate $\left(500 \mathrm{ppm}\right.$ as $\left.\mathrm{SiO}_{2}\right)$ was prepared by dissolving $4.08 \mathrm{~g}$ of $\mathrm{Na}_{2} \mathrm{SiO}_{3} \cdot 5 \mathrm{H}_{2} \mathrm{O}$ in $2 \mathrm{~L}$ of deionized water (a non-glass container must be used), followed by overnight rigorous stirring. Stock solutions of the additives in water (PEI, CMI, PAM-co$\mathrm{AA}, \mathrm{PCH})$ were $1 \% \mathrm{w} / \mathrm{v}(10.000 \mathrm{ppm})$. The following solutions were prepared for the silicomolybdate spectrophotometric detection test: $(a)$ An ammonium molybdate solution: $10 \mathrm{~g}$ of ammonium molybdate was dissolved in $100 \mathrm{~mL}$ of water, and its $\mathrm{pH}$ was adjusted between 7 and 8 with $\mathrm{NaOH}$ to avoid precipitation of ammonium molybdate. (b) A hydrochloric acid solution: one volume $37 \% \mathrm{HCl}$ was mixed with equal volume water. $(c)$ An oxalic acid solution: $8.75 \mathrm{~g}$ of oxalic acid was dissolved in $100 \mathrm{~mL}$ of water. All solutions were kept in polyethylene containers (glass containers must be avoided to minimize $\mathrm{SiO}_{2}$ dissolution and silicate leaching into the test solutions). $\mathrm{HCl}$ and ammonium molybdate were kept in the fridge, while silica and oxalic acid solution were kept at room temperature.

\section{Silicic acid polycondensation protocol ("control" experiment)}

$100 \mathrm{~mL}$ from the $500 \mathrm{ppm}$ sodium silicate stock solution (see above) was placed in a polyethylene beaker and the initial $\mathrm{pH}$ was found 11.8. The $\mathrm{pH}$ is then adjusted to $7.00 \pm$ 
0.1 by addition of $\mathrm{HCl}$ and/or $\mathrm{NaOH}$, as needed (the change in the resulting volume was minor and did not affect any of the calculations). Then, the beaker was covered with plastic membrane and set aside without stirring. The solutions were checked for molybdatereactive silica by the silicomolybdate method every 1 hour for the first 8 hours or after 24 , 48, and 72 hours after the $\mathrm{pH}$ adjustment (see below). All experiments (control and in the presence of inhibitor and co-inhibitor) were treated in precisely the same way.

\section{Silicic acid polycondensation in presence of PEI and co-inhibitors}

$100 \mathrm{~mL}$ portions of the $500 \mathrm{ppm}$ sodium silicate stock solution (see above) were placed in polyethylene containers. In each container, different volumes of pure PEI or PEI and coinhibitor (from the prepared $10.000 \mathrm{ppm}$ stock solutions) were added to achieve desirable concentration. After that, the same procedure as the "control" protocol was followed.

\section{Determination of molybdate-reactive silica}

Molybdate-reactive silica (mainly mono- and some disilicic acid) was quantified using the well established silicomolybdate spectrophotometric method [35-40]. As in our previous studies [18-32], we used the "yellow molybdate" method (using Spectrophotometer $H A C H D R / 890$ ) as follows: $2 \mathrm{~mL}$ from the working solution is filtered through a $0.45 \mu \mathrm{m}$ syringe filter and then diluted to $25 \mathrm{~mL}$ in a special cylindrical cell of $1 \mathrm{~cm}$ path length, made of quartz. Next, $1 \mathrm{~mL}$ of ammonium molybdate stock solution and $0.5 \mathrm{~mL}$ of $\mathrm{HCl}$ (1:1 dilution of the concentrated solution) are added to the sample cell, the solution is shaken well and left standing for $10 \mathrm{~min}$. Afterward $1 \mathrm{~mL}$ of oxalic acid solution is added and the cell contents are mixed well. The solution is set aside for $2 \mathrm{~min}$. The photometer is now set to "zero absorbance" using a sample of deionized water ("blank"). Finally, the sample absorbance is measured (at $452 \mathrm{~nm}$ ) and is expressed as "ppm $\mathrm{SiO}_{2}$ ". The detectable concentration range for this specific protocol is $6-75 \mathrm{ppm}$. To calculate the concentration in the original solution, an appropriate dilution factor $(\times 27.5 / 2)$ is applied. The basic working principle of the silicomolybdate test is that ammonium molybdate reacts only with mono- and disilicic acid and any phosphate present and forms yellow-colored complexes. This reaction requires acidic environment in order to take place, and this is why the hydrochloric acid is added to the samples. It should be noted that colloidal silica does not participate in the reaction and thus does not affect the intensity of yellow color, which is proportional to the concentration of the reactive silica present in the sample experiment. Oxalic acid is added to destroy any molybdophosphoric acid formed, leaving the silicomolybdate complex intact, and thus eliminating any color interference from phosphates.

\section{Results and Discussion}

We previously reported some preliminary results on the inhibitory activity of PEI for silica control $[26,28]$. PEI showed a peculiar inhibition behavior. Specifically, its inhibitory 
activity dropped as its concentration increased. This phenomenon was very intriguing and deserved further study. Hence, the concentration dependence of the inhibition of PEI is presented in Table 1 (3-day experiment duration) and plotted in Figure 4.

Table 1. Silica inhibition measurements with PEI (10, 20, 40, 60 and $80 \mathrm{ppm})$ in long-term experiments (3 days).

\begin{tabular}{ccccccc}
\hline \multirow{2}{*}{ Time (hours) } & Control & \multicolumn{5}{c}{ PEI concentration (in ppm) } \\
\cline { 3 - 7 } & & $\mathbf{1 0}$ & $\mathbf{2 0}$ & $\mathbf{4 0}$ & $\mathbf{6 0}$ & $\mathbf{8 0}$ \\
\hline 24 & 193 & 275 & 224 & 216 & 182 & 186 \\
48 & 169 & 210 & 193 & 179 & 164 & 164 \\
72 & 160 & 190 & 186 & 173 & 165 & 157 \\
\hline
\end{tabular}

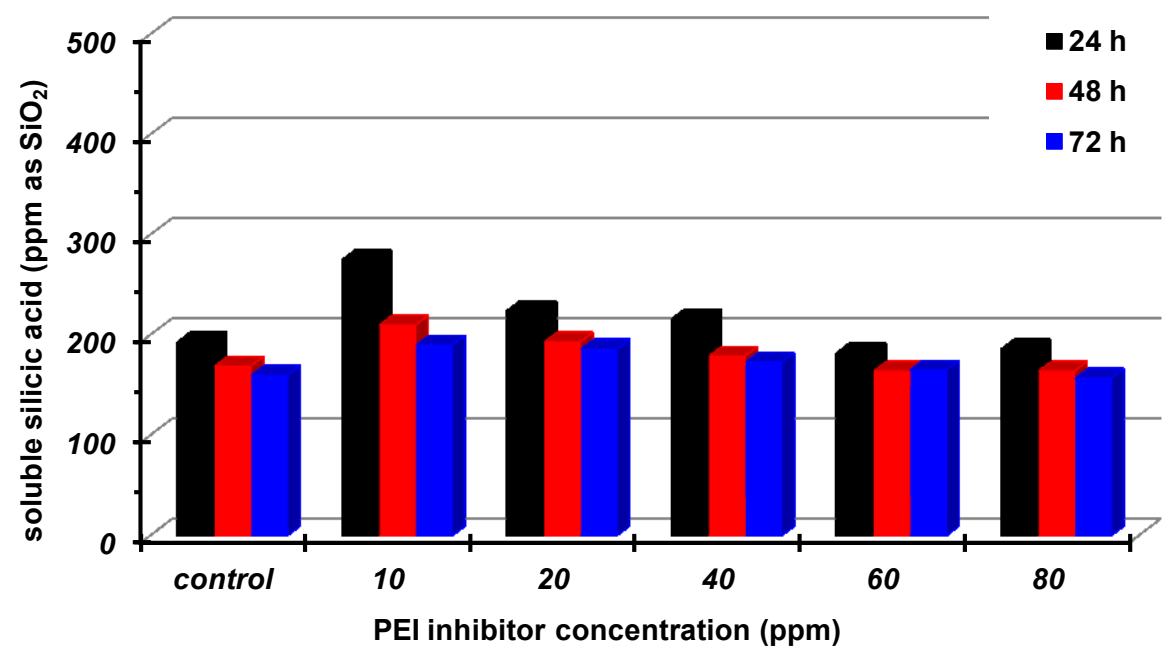

Figure 4. Silica inhibitory activity of PEI in long-term experiments (3 days).

A general observation is that PEI is a "mediocre" silica inhibitor, with its optimum concentration being $10 \mathrm{ppm}$. As PEI concentration increases, its inhibitory activity is reduced. This confirms our earlier observations $[26,28]$ and is reminiscent of the behavior of polyallylamine (PALAM) [41]. Silicic acid polymerizes to yield amorphous silica at $\mathrm{pH}=7$ at a fairly fast rate. In the absence of inhibitors, $193 \mathrm{ppm}$ remain soluble after 24 hours, $169 \mathrm{ppm}$ after $48 \mathrm{~h}$, and $160 \mathrm{ppm}$ after $72 \mathrm{~h}$. PEI was tested at various dosages (at $\mathrm{pH}=7$ ) ranging from $10 \mathrm{ppm}$ up to $80 \mathrm{ppm}$, and it was discovered that the dosage of $10 \mathrm{ppm}$ was the optimum. At this dosage it substantially increases the levels of soluble silicic acid: $275 \mathrm{ppm}$ (after $24 \mathrm{~h}$ ), $210 \mathrm{ppm}$ (after $48 \mathrm{~h}$ ) and $190 \mathrm{ppm}$ (after $72 \mathrm{~h}$ ), see Figure 4. 
The optimum concentration of $10 \mathrm{ppm}$ was further studied in "short-term" $(8 \mathrm{~h})$ experiments in order to gain further insight into the inhibition event during the first stages. The results are presented in Table 2 (8-hour experiment duration) and plotted in Figure 5. Silicic acid polymerization proceeds gradually in the presence of $10 \mathrm{ppm}$ PEI, however, the drop in soluble silicic acid is consistently above the "control". It is also important to mention that almost $100 \mathrm{ppm}$ of silica remain soluble above the control after the first 8 hours (Figure 5).

However, in the presence of PEI as inhibitor, turbid solutions are noted. This means that amorphous silica precipitates are present, mixed, perhaps, with PEI polymer. These precipitates form due to the ability of the cationic PEI polymer to coagulate the uninhibited colloidal silica particles. In order to "relieve" the excessive cationic charge, we thought of using a second anionic polymer "add-on", co-inhibitor, in hope that it will partially neutralize the positively charged amine groups of PEI, and thus reduce its excessive cationic charge.

Table 2. Silica inhibition measurements with PEI (10 ppm) in short-term experiments ( 8 hours).

\begin{tabular}{ccc}
\hline & \multicolumn{2}{c}{ PEI concentration (in ppm) } \\
\cline { 2 - 3 } Time (hours) & control & $\mathbf{1 0}$ \\
\hline $\mathbf{1}$ & 466 & 400 \\
$\mathbf{2}$ & 419 & 392 \\
$\mathbf{4}$ & 377 & 380 \\
$\mathbf{5}$ & 323 & 380 \\
$\mathbf{6}$ & 323 & 369 \\
$\mathbf{7}$ & 275 & 362 \\
$\mathbf{8}$ & 257 & 363 \\
& 243 & 340 \\
\hline
\end{tabular}




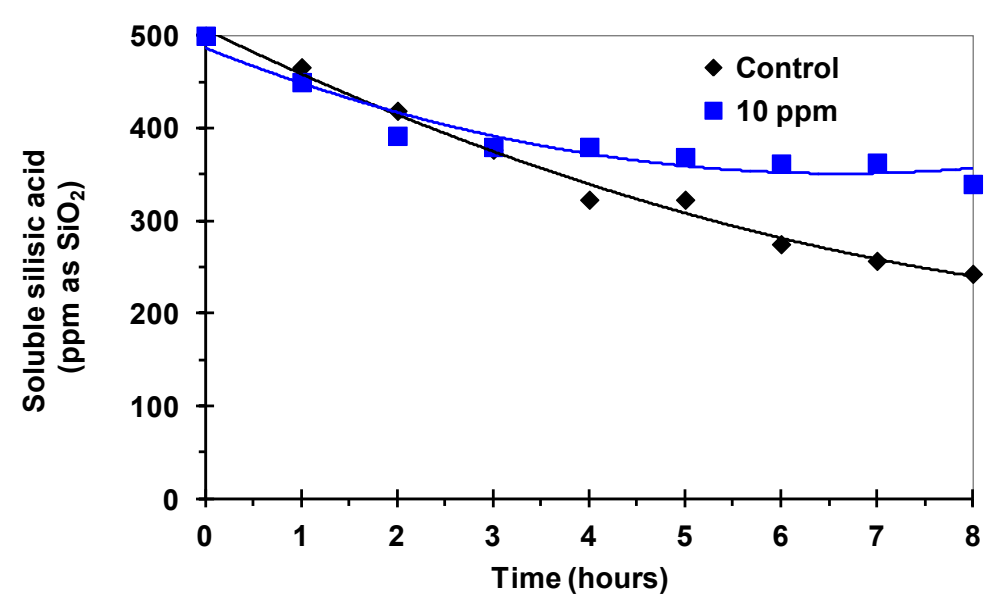

Figure 5. Silica inhibitory activity of PEI (10 ppm) in short-term experiments ( 8 hours).

The first co-inhibitor that was evaluated was CMI. Inhibitory activity results with PEI (10 ppm) and its blend with CMI (10 ppm) are presented in Table 3 and Figure 6 in longterm experiments $(24 \mathrm{~h})$.

Table 3. Silica inhibition measurements in the presence of a synergistic blend of PEI (10 ppm) and CMI (10 ppm).

\begin{tabular}{cccc}
\hline Time (hours) & Control & \multicolumn{2}{c}{ Inhibitor Blend Composition } \\
\cline { 3 - 4 } & & $\mathbf{1 0} \mathbf{~ p p m ~ P E I}$ & $\begin{array}{c}\mathbf{1 0} \text { ppm PEI } \\
+\mathbf{1 0} \text { ppm CMI }\end{array}$ \\
\hline 24 & 182 & 232 & 396 \\
48 & 139 & 183 & 235 \\
72 & 147 & 149 & 191 \\
\hline
\end{tabular}

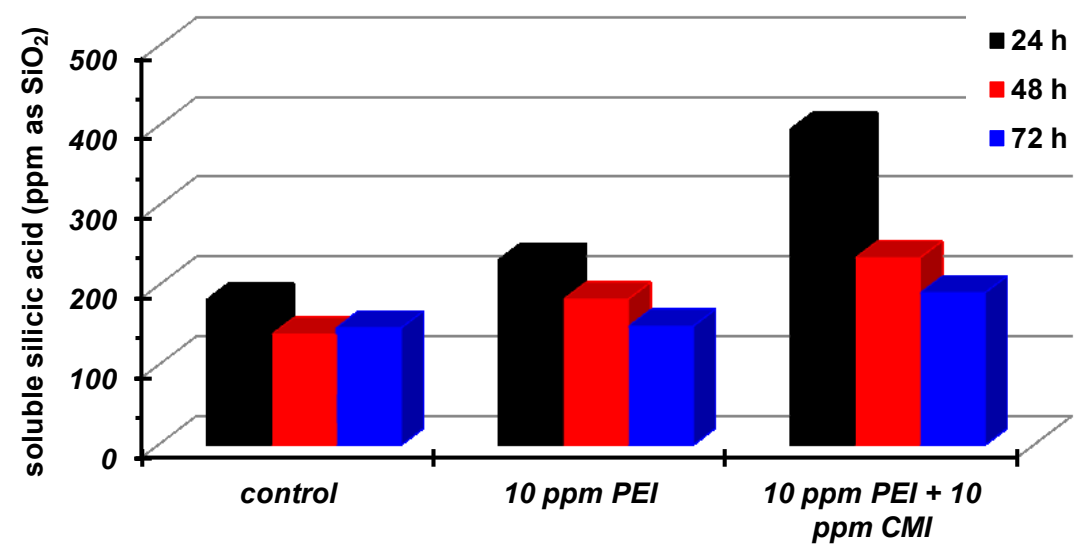

PEI blend inhibitor concentration (ppm)

Figure 6. Silica inhibitory activity of $10 \mathrm{ppm}$ PEI and its blend with CMI (10 ppm). 
Based on the measurements of Table 3 and Figure 6, it is apparent that CMI exerts an enhancing effect on PEI. Specifically, in the presence of $10 \mathrm{ppm}$ PEI (alone) $50 \mathrm{ppm}$ silicic acid above the "control" are measured after $24 \mathrm{~h}$. Importantly, when $10 \mathrm{ppm}$ CMI are added, $164 \mathrm{ppm}$ silicic acid above that with PEI are recorded (and $214 \mathrm{ppm}$ above the control), after $24 \mathrm{~h}$. This is significant proof that CMI causes solubilization of PEI, and thus, there is no polymer entrapment into the silica matrix. This is corroborated by the absence of silica precipitates.

The inhibitory activity of $10 \mathrm{ppm}$ PEI in combination with CMI (10 ppm) or PCH $(40 \mathrm{ppm})$ was evaluated in short-term experiments $(8 \mathrm{~h})$. These results are presented in Table 4 and Figure 7.

Table 4. Silica inhibition measurements in the presence of a synergistic blend of PEI (10 ppm) and CMI $(10 \mathrm{ppm})$, or PCH (40 ppm) in short-term experiments $(8 \mathrm{~h})$.

\begin{tabular}{ccccc}
\hline \multirow{2}{*}{ Time (hours) } & Control & \multicolumn{3}{c}{ Inhibitor Blend Composition } \\
\cline { 3 - 5 } & & $\mathbf{1 0}$ ppm PEI & $\begin{array}{c}\mathbf{1 0} \mathbf{~ p p m ~ P E I ~ + ~} \\
\mathbf{1 0} \mathbf{~ p p m ~ C M I}\end{array}$ & $\begin{array}{c}\mathbf{1 0} \text { ppm PEI + } \\
\mathbf{4 0} \text { ppm PCH }\end{array}$ \\
\hline $\mathbf{1}$ & 448 & 400 & 429 & 408 \\
$\mathbf{2}$ & 395 & 392 & 399 & 381 \\
$\mathbf{3}$ & 363 & 380 & 424 & 363 \\
$\mathbf{4}$ & 318 & 380 & 404 & 362 \\
$\mathbf{5}$ & 283 & 369 & 407 & 366 \\
$\mathbf{6}$ & 263 & 362 & 378 & 369 \\
$\mathbf{7}$ & 243 & 363 & 366 & 363 \\
$\mathbf{8}$ & 219 & 340 & 327 & 337 \\
\hline
\end{tabular}




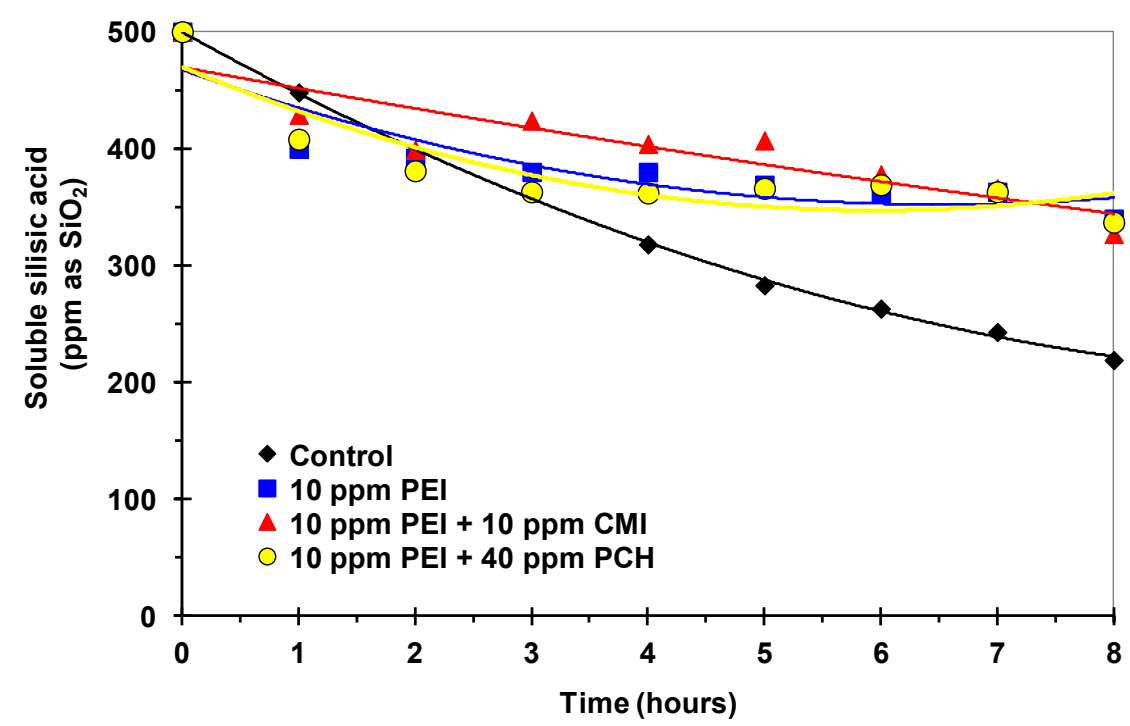

Figure 7. Silica inhibition measurements with $10 \mathrm{ppm}$ PEI and its blends with CMI (10 ppm) or PCH (40 ppm).

Based on these results it is evident that during the first $8 \mathrm{~h}$ of the silica inhibition event the inhibitor blends do not offer additional inhibitory enhancement beyond that of PEI alone. Hence, the influence of these co-inhibitors on the activity of PEI takes effect after 8 hours and before 24 hours.

PEI is marginally effective in silica inhibition at $20 \mathrm{ppm}$ concentration, stabilizing only $30 \mathrm{ppm}$ silicic acid beyond the "control", after $24 \mathrm{~h}$ (see Table 1 and Figure 4). Hence, the blends of PEI (at $20 \mathrm{ppm}$ ) with various co-inhibitors would be worth-studying. Long-term (3 days) inhibitory activity results of PEI (at $20 \mathrm{ppm}$ ) and its synergistic blends with the co-inhibitor "add-ons" PAA $\left(\mathrm{PO}_{3} \mathrm{H}_{2}\right)_{2}$, PAA (2 kDa), PAM-co-AA, and PCH (all in $20 \mathrm{ppm}$ concentration) additions, are presented in Table 5 and Figure 8 . To assist the reader, we have added the silicic acid values on the $24 \mathrm{~h}$ bars.

Table 5. Long-term silica inhibition measurements with $20 \mathrm{ppm}$ PEI and its synergistic blends with the co-inhibitors PAA $\left(\mathrm{PO}_{3} \mathrm{H}_{2}\right)_{2}$, PAA (2 kDa), PAM-co-AA, and PCH.

\begin{tabular}{|c|c|c|c|c|c|c|}
\hline \multirow{2}{*}{$\begin{array}{c}\text { Time } \\
\text { (hours) }\end{array}$} & \multirow{2}{*}{ Control } & \multicolumn{5}{|c|}{ Inhibitor Blend Composition } \\
\hline & & $\begin{array}{l}20 \text { ppm } \\
\text { PEI }\end{array}$ & $\begin{array}{c}20 \text { ppm PEI + } \\
20 \mathrm{ppm} \\
\operatorname{PAA}_{\left(\mathrm{PO}_{3} \mathrm{H}_{2}\right)_{2}}\end{array}$ & $\begin{array}{c}20 \text { ppm PEI + } \\
20 \text { ppm PAA } \\
\text { (2 KDa) }\end{array}$ & $\begin{array}{c}20 \text { ppm PEI + } \\
20 \text { ppm PAA-co- } \\
\text { AA }\end{array}$ & $\begin{array}{l}20 \text { ppm PEI + } \\
20 \text { ppm PCH }\end{array}$ \\
\hline 24 & 193 & 224 & 337 & 452 & 404 & 322 \\
\hline 48 & 169 & 193 & 243 & 286 & 381 & 246 \\
\hline 72 & 160 & 186 & 191 & 216 & 329 & 224 \\
\hline
\end{tabular}




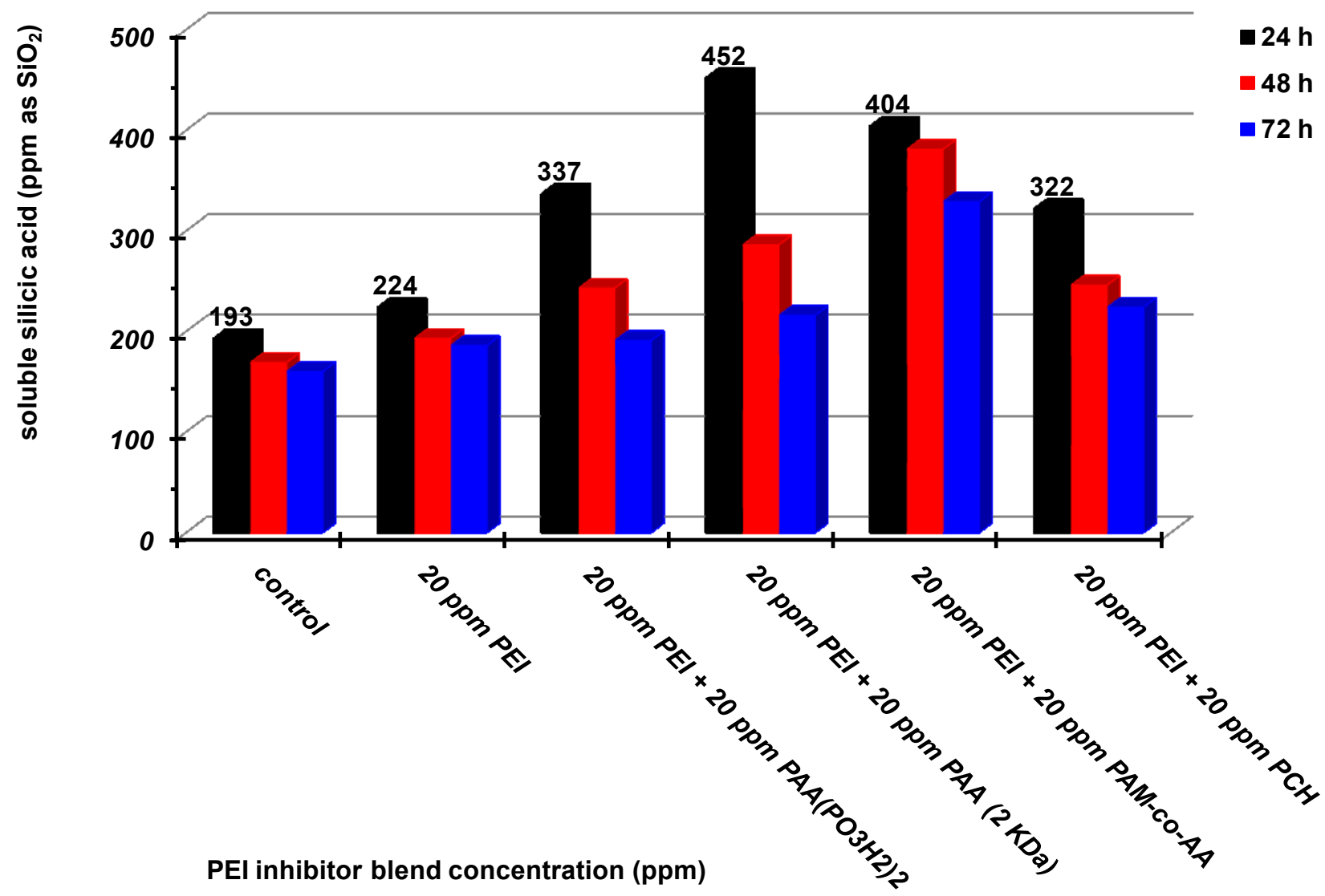

Figure 8. Bar graph with silica inhibition measurements in the presence of PEI (20 ppm) and its synergistic blends with PAA $\left(\mathrm{PO}_{3} \mathrm{H}_{2}\right)_{2}$, PAA (2 kDa), PAM-co-AA, and PCH (all at $20 \mathrm{ppm})$.

An important observation is that all co-inhibitors exhibit an enhancement effect on the inhibitory activity of PEI, which is more profound in the $24 \mathrm{~h}$ measurements. Specifically, and based on the $24 \mathrm{~h}$ results, the following ranking can be put forth for the enhancement effect of the co-inhibitors:

$$
\mathrm{PCH}<\mathrm{PAA}\left(\mathrm{PO}_{3} \mathrm{H}_{2}\right)_{2}<\text { PAM-co-AA }<\text { PAA }(2 \mathrm{kDa})
$$

It is important to note, however, that PAM-co-AA is able to enhance the inhibitory activity of PEI beyond the $24 \mathrm{~h}$ limit. Specifically, the synergistic blend " $20 \mathrm{ppm}$ PEI + 20 ppm PAM-co-AA" maintains 381 ppm silicic acid after 48 hours, and 329 ppm silicic acid after 72 hours. Hence, this combination is more suitable for good inhibition results on a longer time scale.

Lastly, we selected the three co-inhibitors PAA (2 kDa) (20 ppm), PAM-co-AA $(60 \mathrm{ppm})$ and CMI (20 ppm) and studied them for their inhibitory enhancement of PEI $(20 \mathrm{ppm})$ in "short-term" experiments ( 8 hours). These results are presented in Table 6 and Figure 9 in short-term experiments. 
Table 6. Silica inhibition measurements with 20 ppm PEI and its blend with PAA (2 kDa) (20 ppm), PAM-co-AA (60 ppm) and CMI (20 ppm).

\begin{tabular}{cccccc}
\hline \multirow{2}{*}{$\begin{array}{c}\text { Time } \\
\text { (hours) }\end{array}$} & Control & \multicolumn{4}{c}{ Inhibitor Blend Composition } \\
\cline { 2 - 6 } & & $\begin{array}{c}\text { 20 ppm } \\
\text { PEI }\end{array}$ & $\begin{array}{c}\text { 20 ppm PEI + 60 } \\
\text { ppm PAM-co-AA }\end{array}$ & $\begin{array}{c}\text { 20 ppm PEI + 20 } \\
\text { ppm PAA (2 kDa) }\end{array}$ & $\begin{array}{c}\text { 20 ppm PEI + 20 } \\
\text { ppm CMI }\end{array}$ \\
\hline $\mathbf{1}$ & 448 & 344 & 439 & 424 & 418 \\
$\mathbf{2}$ & 395 & 323 & 414 & 395 & 406 \\
$\mathbf{3}$ & 363 & 314 & 386 & 400 & 381 \\
$\mathbf{4}$ & 318 & 303 & 418 & 381 & 384 \\
$\mathbf{5}$ & 283 & 301 & 392 & 397 & 360 \\
$\mathbf{6}$ & 263 & 294 & 371 & 402 & 366 \\
$\mathbf{7}$ & 243 & 294 & 355 & 385 & 366 \\
$\mathbf{8}$ & 219 & 259 & 337 & 382 & 351 \\
\hline
\end{tabular}

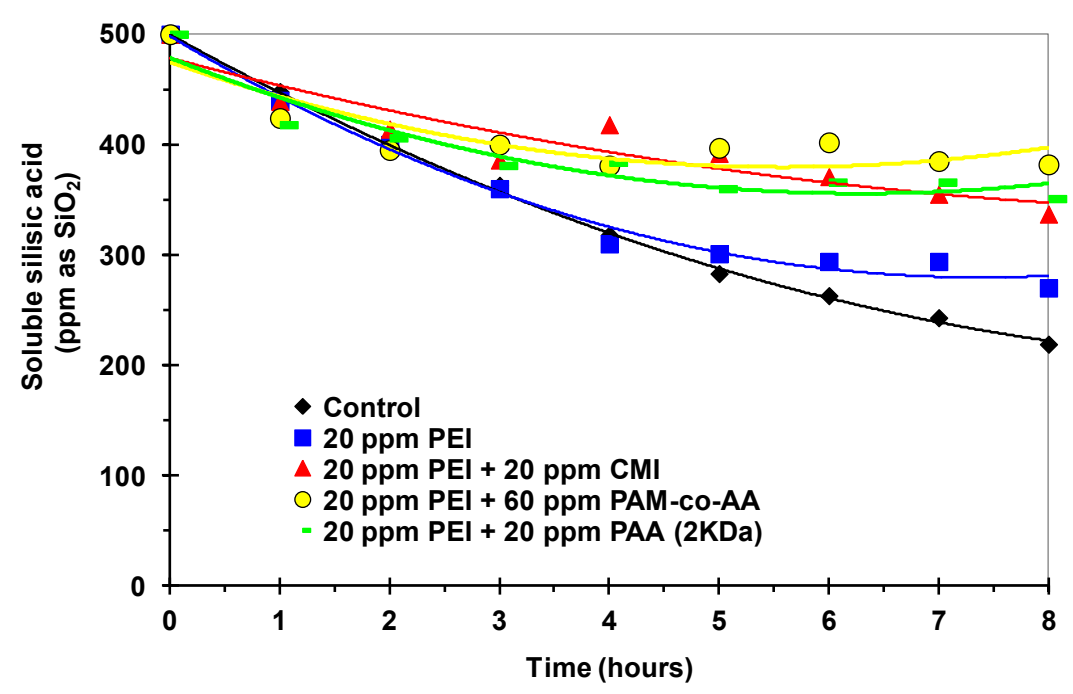

Figure 9. Silica inhibition measurements with $20 \mathrm{ppm}$ PEI and its blend with PAA (2 kDa) (20 ppm), PAM-co-AA (60 ppm) and CMI (20 ppm).

It becomes evident that the inhibitory enhancement of PEI in the presence of coinhibitors that was observed in the "long-term" experiments (3-days, Table 5, Figure 8) is confirmed in the "short-term" experiments ( 8 hours). All three co-inhibitors (PAA (2 kDa), PAM-co-AA and CMI) exert similar enhancement effects, however, PAM-co-AA was added at $60 \mathrm{ppm}$ concentration, whereas the other two, PAA and CMI, were utilized at 20 ppm concentration. 


\section{Conclusions/Perspectives}

In this paper we reported the inhibitory efficiency of polyethyleneimine (PEI) and its multifunctional synergistic mixtures with anionic polyelectrolytes for the control of silica scale. PEI is proven to be an "acceptable" silica scale inhibitor in $10 \mathrm{ppm}$ addition (Figures 3 and 4). However, the excess of cationic charge causes the formation of precipitates that consist of silica-inhibitor aggregates and clusters. A blend of PEI and CMI (10 ppm each) is proven to be most efficient, stabilizing almost $165 \mathrm{ppm}$ additional silicic acid than that stabilized by PEI alone.

PEI at $20 \mathrm{ppm}$ is marginally effective due to the increase of cationic charge (compared to the $10 \mathrm{ppm}$ dosage) in solution. Again, the extensive cationic charge on the polymer backbone may be detrimental to its inhibitory activity, and this may, in part, be corrected and improved by the use of secondary, anionic polymer add-ons. In this case, PAM-co-AA, CMI and PAA (2KDa) were proven to be the most beneficial for PEI. Synergistic blends with the aforementioned anionic molecules relieve the excess cationic charge and stabilize silicic acid up to $382 \mathrm{ppm}$ (PAA 2kDa $20 \mathrm{ppm}$ ) after 8 hours.

The results presented herein strongly support the conclusion that inhibition of silica scale is a demanding task, often requiring "exotic" approaches and strategies. Towards this goal, several other inhibitor molecules are under investigation in our laboratory $[42,43]$.

\section{Acknowledgments}

KDD thanks the EU for funding the Research Program SILICAMPS-153, under the ERA.NET-RUS Pilot Joint Call for Collaborative S\&T projects.

\section{References}

1. J. C. Cowan and D. J. Weintritt, Water-Formed Scale Deposits, Gulf Publishing Co., Houston, TX, 1976.

2. K. D. Demadis, Water \& Wastewater International, 2005/2006, December/January, 21.

3. K. D. Demadis, in Compact Heat Exchangers and Enhancement Technology for the Process Industries, Ed. R. K. Shah, Begell House Inc., New York, 2003, pp 483-490.

4. T. R. Bott, Fouling Notebook, Rugby, Institution of Chemical Engineers, 1990.

5. Z. Amjad, Mineral Scale Formation and Inhibition, Plenum Press, New York, 1995.

6. T. R. Bott, Fouling of Heat Exchangers, Elsevier Science, 1995.

7. S. H. Chan, Heat and mass transfer in fouling, in Annual Review of heat transfer, Begell House Inc., New York, 1992, pp. 363-402.

8. Z. Amjad, Science and Technology of Industrial Water Treatment, CRC Press, London, 2010.

9. K. D. Demadis, B. Yang, P. R. Young, D. L. Kouznetsov and D. G. Kelley, in Advances in Crystal Growth Inhibition Technologies, Ed. Z. Amjad, Plenum Press, New York, 2000, Ch. 16, pp. 215-234. 
10. R. Sheikholeslami, Fouling of membrane and thermal units: a unified approach. Its principles, assesment, control and mitigation, Balaban Publishers, $1^{\text {st }}$ Edition, 2007.

11. K. D. Demadis and M. Öner, in Green Chemistry Research Trends, Ed. J. T. Pearlman, Nova Science Publishers, New York, 2009, Ch. 8, pp. 265-287.

12. K. D. Demadis, in Desalination Research Progress, Eds. D. J. Delgado and P. Moreno, Nova Science Publishers, Inc., New York, 2008, Ch. 6, pp. 249-259.

13. M. Preari, A. Tsistraki and K. D. Demadis, in Mineral Scales in Biological and Industrial Systems, Taylor and Francis, New York, 2013, Ch. 12, pp. 215-226.

14. P. Meyers, International Water Conference, 1999, Paper 64.

15. K. D. Demadis, in Science and Technology of Industrial Water Treatment, Ed. Z. Amjad, CRC Press, London, 2010, Ch. 10, pp. 179-203.

16. Y. Tang, W. Yang, X. Yin, Y. Liu, P. Yin and J. Wang, Desalination, 2008, 228, 55.

17. S. M. Chemtob, G. R. Rossman and J. F. Stebbins, Amer. Mineralogist, 2012, 97, 203.

18. K. D. Demadis, E. Neofotistou, E. Mavredaki, M. Tsiknakis, E.-M. Sarigiannidou and S. D. Katarachia, Desalination, 2005, 179, 281.

19. K. D. Demadis and E. Neofotistou, Mater. Perform., 2004, 43, no. 4, 38.

20. E. Neofotistou and K. D. Demadis, Coll. Surf. A: Physicochem. Eng. Asp., 2004, 242, 213.

21. E. Neofotistou and K. D. Demadis, Desalination, 2004, 167, 257.

22. K. D. Demadis, Power, 2004, 148, no. 6, 19.

23. K. D. Demadis, J. Chem. Technol. Biotechnol., 2005, 80, 630.

24. E. Mavredaki, E. Neofotistou and K. D. Demadis, Ind. Eng. Chem. Res., 2005, 44, 7019.

25. K. D. Demadis and E. Mavredaki, Env. Chem. Lett., 2005, 3, 127.

26. K. D. Demadis and A. Stathoulopoulou, Mater. Perform., 2005, 45, no. 1, 40.

27. K. D. Demadis, E. Mavredaki, A. Stathoulopoulou, E. Neofotistou and C. Mantzaridis, Desalination, 2007, 213, 38.

28. K. D. Demadis and A. Stathoulopoulou, Ind. Eng. Chem. Res., 2006, 45, 4436.

29. K. D. Demadis and E. Neofotistou, Chem. Mater., 2007, 19, 581.

30. K. D. Demadis, M. Preari and I. Antonakaki, Pure Appl. Chem., 2014, 86, 1663.

31. K. D. Demadis and M. Preari, Des. Wat. Treat., 2015, in press.

32. M. Preari, K. Spinde, J. Lazic, E. Brunner and K. D. Demadis, J. Am. Chem. Soc., 2014, 136, 4236.

33. G. R. Kieczykowski, R. B. Jobson, D. G. Melillo, D. F. Reinhold, V. J. Grenda and I. Shinkai, J. Org. Chem., 1995, 60, 8310.

34. A. Heras, N. M. Rodriguez, V. M. Ramos and E. Agullo, Carbohydr. Polym., 2001, 44, 1 .

35. T. Coradin, D. Eglin and J. Livage, Spectroscopy, 2004, 18, 567.

36. G. B. Alexander, J. Am. Chem. Soc., 1953, 75, 5655.

37. V. W. Truesdale, P. J. Smith and C. J. Smith, Analyst, 1979, 897. 
38. V. W. Truesdale and C. J. Smith, Analyst, 1975, 797.

39. V. W. Truesdale and C. J. Smith, Analyst, 1975, 203.

40. A. D. Eaton, L. S. Clesceri, E. W. Rice, A. E. Greenberg and M. H. Franson, in Standard Methods for Examination of Water and Wastewater, American Public Health Association, 2005.

41. A. Spinthaki, A. Stathoulopoulou and K. D. Demadis, Int. J. Corros. Scale Inhib., 2015, 4, no. 1, 85. doi: $10.17675 / 2305-6894-2015-4-1-085-095$

42. K. D. Demadis, K. Pachis, A. Ketsetzi and A. Stathoulopoulou, Adv. Colloid Interf. Sci., 2009, 151, 33.

43. K. D. Demadis, A. Ketsetzi, K. Pachis and V. M. Ramos, Biomacromolecules, 2008, 9, 3288.

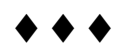

